\title{
Strain patterns along the Kaparelli-Asopos rift (central Greece) from campaign GPS data
}

\author{
Aggeliki Marinou ${ }^{1}{ }^{\star}$, Athanassios Ganas ${ }^{2}$, Kalliopi Papazissi ${ }^{1}$, Demitris Paradissis ${ }^{1}$ \\ ${ }^{1}$ Higher Geodesy Laboratory, N.T.U.A., Faculty of Rural and Surveying Engineering, Zographos, Greece \\ ${ }^{2}$ Institute of Geodynamics, N.O.A., Athens, Greece
}

\section{Article history}

Received October 8, 2013; accepted March 25, 2015.

Subject classification:

GPS, Strain rate, Kaparelli, Active fault, Central Greece.

\begin{abstract}
We present results from four GPS campaigns in the broader KaparelliAsopos area in central Greece. This area is undergoing extension as demonstrated by seismological, geodetic and geological data. The eastwest striking Kaparelli normal fault ruptured during the March 4, 1981, $M=6.3$ earthquake and created km-long surface breaks with the downthrown side to the south. The geodetic results include: determination of station coordinates in the ITRF 2005 frame, computation of station velocities with respect to stable Europe and strain rate tensor estimates. The pattern of velocities along the east-west direction (parallel to the rift axis; $40 \mathrm{~km} \mathrm{E}-W \times 12 \mathrm{~km} \mathrm{~N}-\mathrm{S}$ ) and azimuth of strain axes are compared to geological data and to other GPS results in central Greece. We find that strain in this region consists of an amount of shortening ( $66 \mathrm{~ns} / \mathrm{yr}$ ) in the direction approximately $N 58^{\circ} \mathrm{E}$, and about three times more extension (187 ns/yr) at $N 32^{\circ} \mathrm{W}$. A large change in strain orientation (from NW to NNE) is observed from west to east, along the active faults of Asopos rift in agreement with fault slip data. This change signifies the need for using local GPS networks to map local strain rate patterns in actively extending regions of Greece.
\end{abstract}

\section{Introduction}

Central Greece is one of the most tectonically active and rapidly extending regions on planet Earth. Surface topography and geomorphology are clearly associated with seismic activity along large normal faults [Jackson et al. 1982, Armijo et al. 1996, Roberts and Ganas 2000, Goldsworthy and Jackson 2000, Goldsworthy and Jackson 2001, Ganas et al. 2004, Tsodoulos et al. 2008, Sboras et al. 2010, Walker et al. 2010, Tsimi and Ganas 2015, Whittaker and Walker 2015]. Extension is mainly directed N-S [Clarke et al. 1998, Avallone et al. 2004, Floyd et al. 2010, Chousianitis et al. 2013]. Focal mechanisms of shallow earthquakes (data from Ambraseys and Jackson [1990]; Figure 1) also show normal faulting with the active fault plane dipping at about $45^{\circ}$ for faults at the eastern end of the Gulf of Corinth includ-

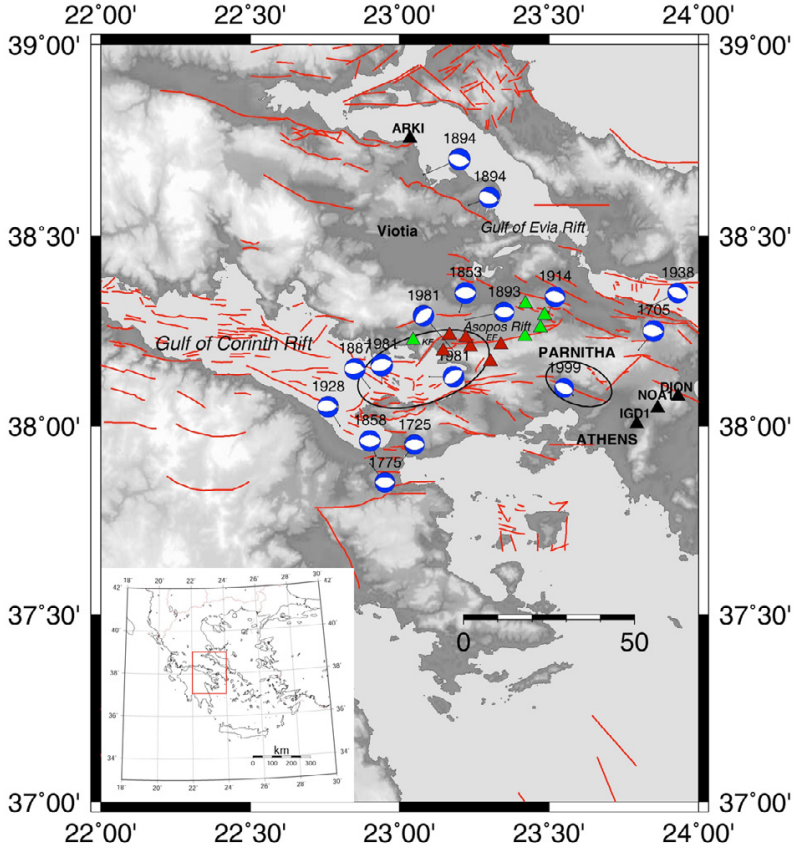

Figure 1. Relief map of Attica, the eastern Gulf of Corinth and Viotia region, central Greece (see lower left inset box for location). Beachballs indicate focal plane solutions of large, shallow earthquakes since 1853 (blue indicates compressional quadrant). Black ellipses are ruptures zones of the 1981 and 1999 earthquakes. Solid triangles represent locations of the Kaparelli GPS network (red installed in 2003 and green in 2005) and permanent stations (in black). Red lines are active faults. KF is Kaparelli Fault. EF is Erithres Fault.

ing south-dipping Kaparelli.

We were motivated to work in this area for several key reasons: first, there is a notable reduction in average fault slip rates as the large E-W faults of the Gulf of Corinth slip fast (1-2 mm/yr; Collier et al. [1998], Bell et al. [2009]) while the large normal faults of the south Viotia and Parnitha (Attica) region to the east slip at about five (5) to ten (10) times less (0.2-0.4 $\mathrm{mm} / \mathrm{yr}$; Ganas et al. [2004], Kokkalas et al. [2007]). It 

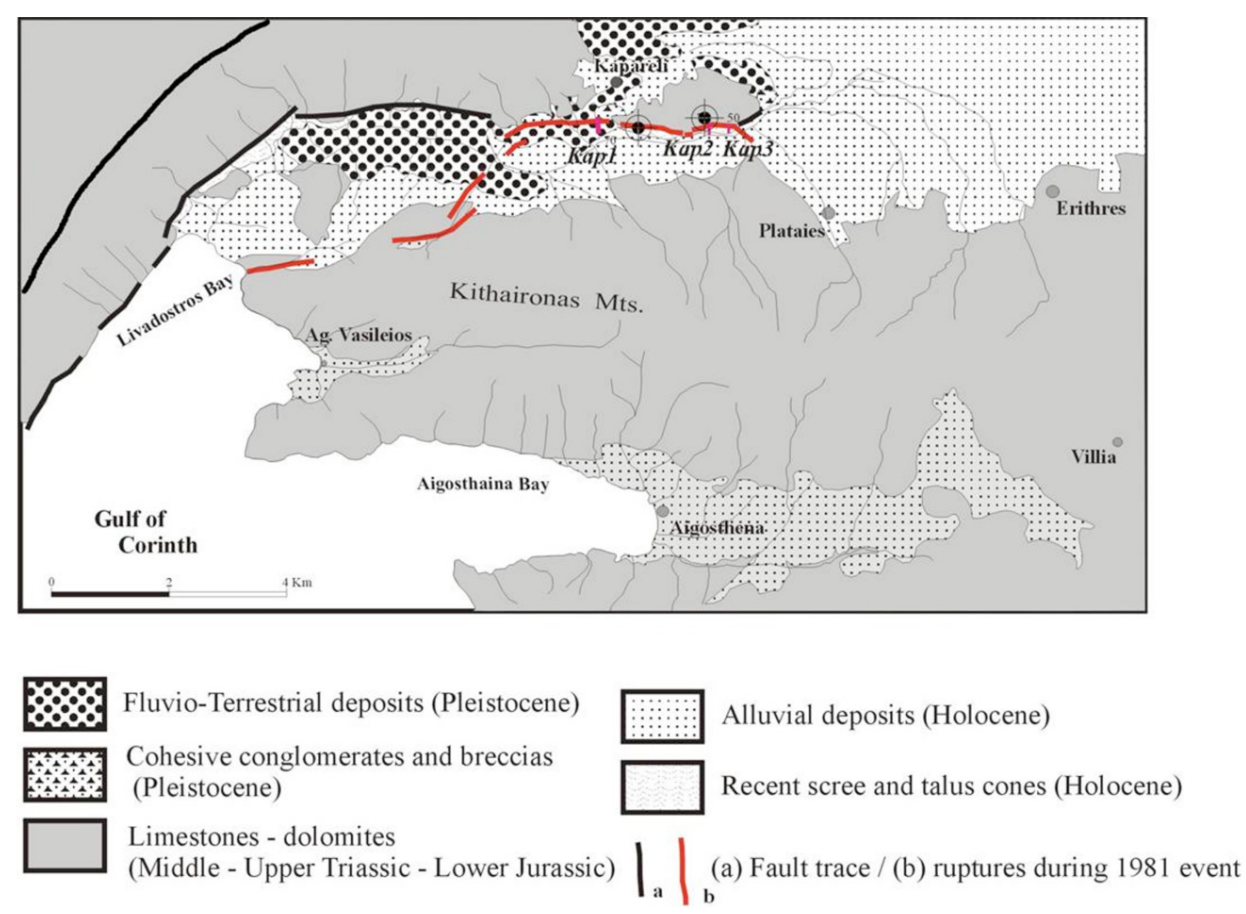

Figure 2. Geological map of the Kaparelli area in central Greece. The 1981 ruptures are shown in red. Kap1, Kap2 and Kap3 denote trenching sites. Map after Kokkalas et al. [2007] and Ganas et al. [2007a].

is interesting to map if this transition in fault slip rates is reflected on the strain pattern by using local GPS networks. A second point concerns the strain rate accumulation along the Kaparelli fault as the geological data show: a) a segmented fault zone with a surface trace bent [Jackson et al. 1982, Poulimenos and Doutsos 1996], b) nearby active faults are segmented [e.g. Roberts and Ganas 2000, Ganas et al. 2004, Ganas et al. 2007b] while geodetic data suggest a total length of $17 \mathrm{~km}$ [Stiros et al. 2007]. So our GPS measurements may be used to study the relation between cumulative fault slip (over a period of 0.5-1 Ma) and present-day strain rate accumulation among the Kaparelli fault segments. Thirdly, the campaign GPS observations may also shed light into fault growth processes by looking at strain azimuth and magnitude along strike as the south Viotia area faults may be in an early phase in the development of large faults (Ganas et al. [2005, 2007b]; see also Mahmoud et al. [2013] for strike-slip faults), a mechanical process that involves the merging of two or more faults of differing strikes, rather than the steady lengthening of a single fault segment. Finally, the results from several GPS campaigns will help us establish both the total magnitude and direction of geodetic strain rate and compare it with the Upper Pleistocene-Holocene faulting record as published in Pavlides et al. [2003], Benedetti et al. [2003] and Kokkalas et al. [2007]. The orientation of the strain axes will be also compared with the configuration of the rupture zones of both the 1981 and the 1999 earthquakes.

\section{Seismological background}

The region of Kaparelli-Erithres has suffered from several catastrophic earthquakes many of which are known from historical references. According to Papazachos and Papazachou [1997] and Ambraseys and Jackson [1990], the vicinity of Thiva (Figure 1) was struck four times since 14th century: in $1321(\mathrm{M}=6.3)$, in 1853 $(M=6.8)$, in $1893(M=6.2)$ and in $1914(M=6.0)$. For the latter they suggest an E-W striking fault located between Kallithea and Asopia villages (Figure 1). For the broader area of Viotia-Attica, other 20th century earthquakes include: the 1938 Oropos $(M=6.0)$, the 1981 Alkyonides $(M=6.7)$ and the 1999 , Athens $(M=5.9)$ event. The first two events occurred inside the highly active grabens of Evia and Corinth Gulfs respectively [Ambraseys and Jackson 1990], while the last one was an "unexpected" event occurred near the city's limits [Papadopoulos et al. 2002]. In February-March 1981 a sequence of three earthquakes with magnitudes greater than 6.3 struck the eastern Gulf of Corinth [Hubert et al. 1996]. South-dipping ruptures appeared on the northern side of the Gulf (Kaparelli region) as a result of the third event (Figure 2; data from Jackson et al. [1982]). In both areas seismic motion occurred along basinbounding faults bringing in contact Mesozoic limestone and alluvial deposits as well as colluvium. Moreover, the Athens 1999 earthquake (about $35 \mathrm{~km}$ to the SE; Figure 1) may have transferred static stress to the KaparelliAsopos area (seismic fault striking WNW-ESE; Atzori et al. [2008]), so any active faults close to failure were "advanced". 
The Kaparelli Fault consists of three segments, two of which were ruptured in 1981 [Jackson et al. 1982]. The two-ruptured segments form left-stepping en echelon geometry, while the third north-western segment of the fault did not rupture (Figure 2). The fault segments are clearly expressed at the surface by nearly continuous scarps. The footwall elevation is $600 \mathrm{~m}$ and lithology is composed of hard, Mesozoic limestone [IGME 1984]. The hanging wall block forms a small basin and contains approximately $200 \mathrm{~m}$ of fluvial-terrestrial deposits of Pleistocene age as well as Holocene alluvium. Recently, three trenches have been excavated across the Kaparelli Fault [Kokkalas et al. 2007]. Their stratigraphic record shows at least three events during the Holocene period, with the 1981 event included. The estimated mean slip rate is $0.28 \mathrm{~mm} / \mathrm{yr}$. Colluvial tectonostratigraphy and analysis of displacements on key horizons suggests surface rupturing events in the order of 0.7-1 m. No major seismic event occurred since March 1981, including the period 2004-2008 when GPS data were collected.

\section{GPS data analysis}

\subsection{The geodetic network (KAPNET)}

The geodetic network in the broad area of Kaparelli Fault consists of eleven (11) points, established by the National Observatory of Athens and the Wroclaw University of Environmental and Life Sciences of Poland [Cacon et al. 2005, Drakatos et al. 2005, Ganas et al. 2007a] (Figure 3a). The main aim of the establishment of the network was to monitor the kinematics of the Kaparelli fault and its connection with the neighbouring active fault of Erithres. Strict geological criteria were set while selecting the location of the stations in order to ensure stable installations. All the geodetic benchmarks were manufactured on limestone.

The KAPNET Network has been measured already four times in total $(2004,2005,2006$ and 2008). The sessions of measurements were about $8-12 \mathrm{~h}$ per point each epoch. The first 2 periods of measurements only six (6) of the geodetic points were occupied and then five (5) more were added mainly to the east part of the region towards the area that Erithres fault is developed. In Figure 3a the distribution of the network as well as the number of occupations for each point are presented. We assume all measured strain is elastic (there is no creep or partial creep). Our GPS measurements show interseismic strain as there have been no $M>6$ earthquakes in this area of central Greece (i.e., no coseismic offsets, nor postseismic effects are measured).

\subsection{The realization of the reference frame}

Nine stations in Eurasia were analyzed and kept fixed in order to align the final velocity field in ITRF2005 (Figure $3 b$ ). For each epoch of the measurements two (2) local permanent stations (Figure 3a) were used forming direct radial baselines with the IGS stations. Before performing the reference frame realization step, we checked the IGS station coordinates for jumps, discrepancies or any other event that could cause the sites to diverge (e.g. earthquakes in the surrounding area). We also did a thorough search on the resulting time series (both for the IGS and the local sites) for any discontinuities or big discrepancies which could stem from the reference frame realization procedure. Thus, the procedure we followed did not introduce any significant bias.
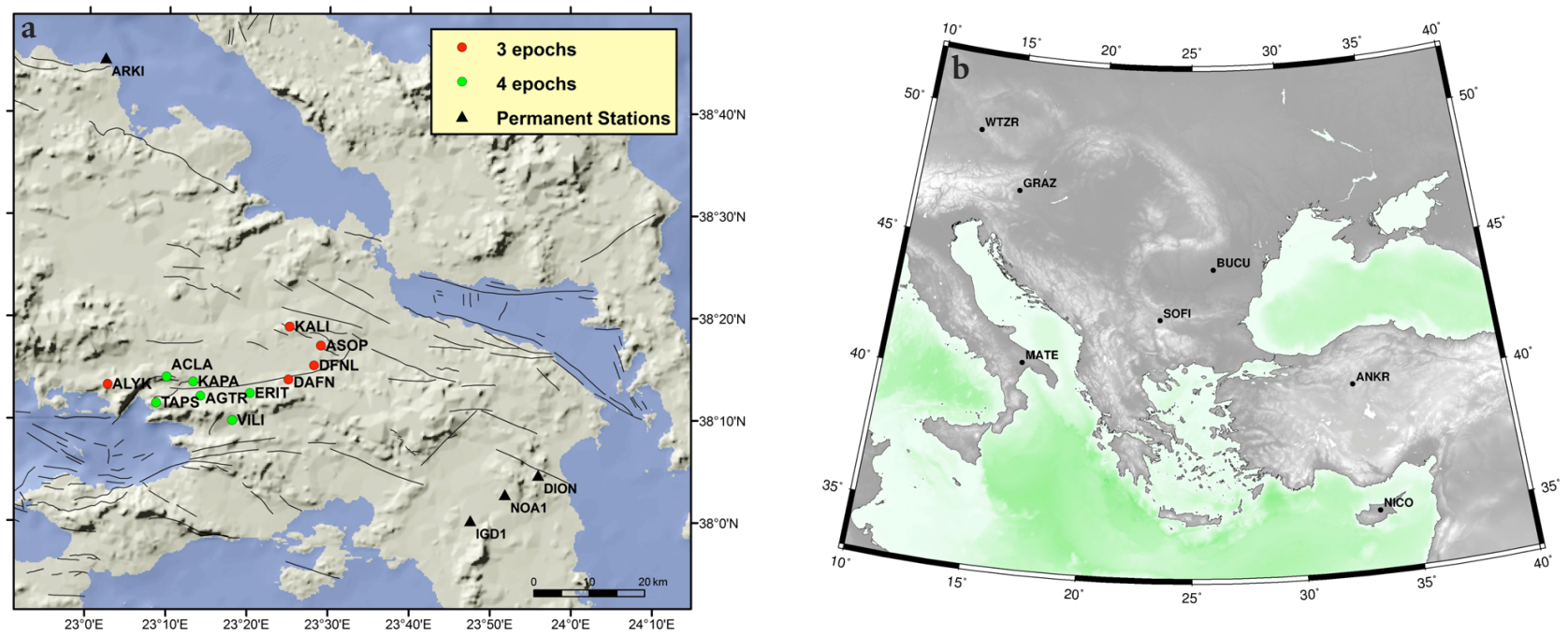

Figure 3. (a) Relief map showing the geodetic network of Kaparelli Area. Station ARKI, NOA1, IGD1 and DION are the permanent geodetic GPS stations near the area of interest that they have been included to the calculation in order to accomplish the realization of the reference frame (b). Map of Europe showing location of stations used to align the GPS velocities to ITRF2005. 

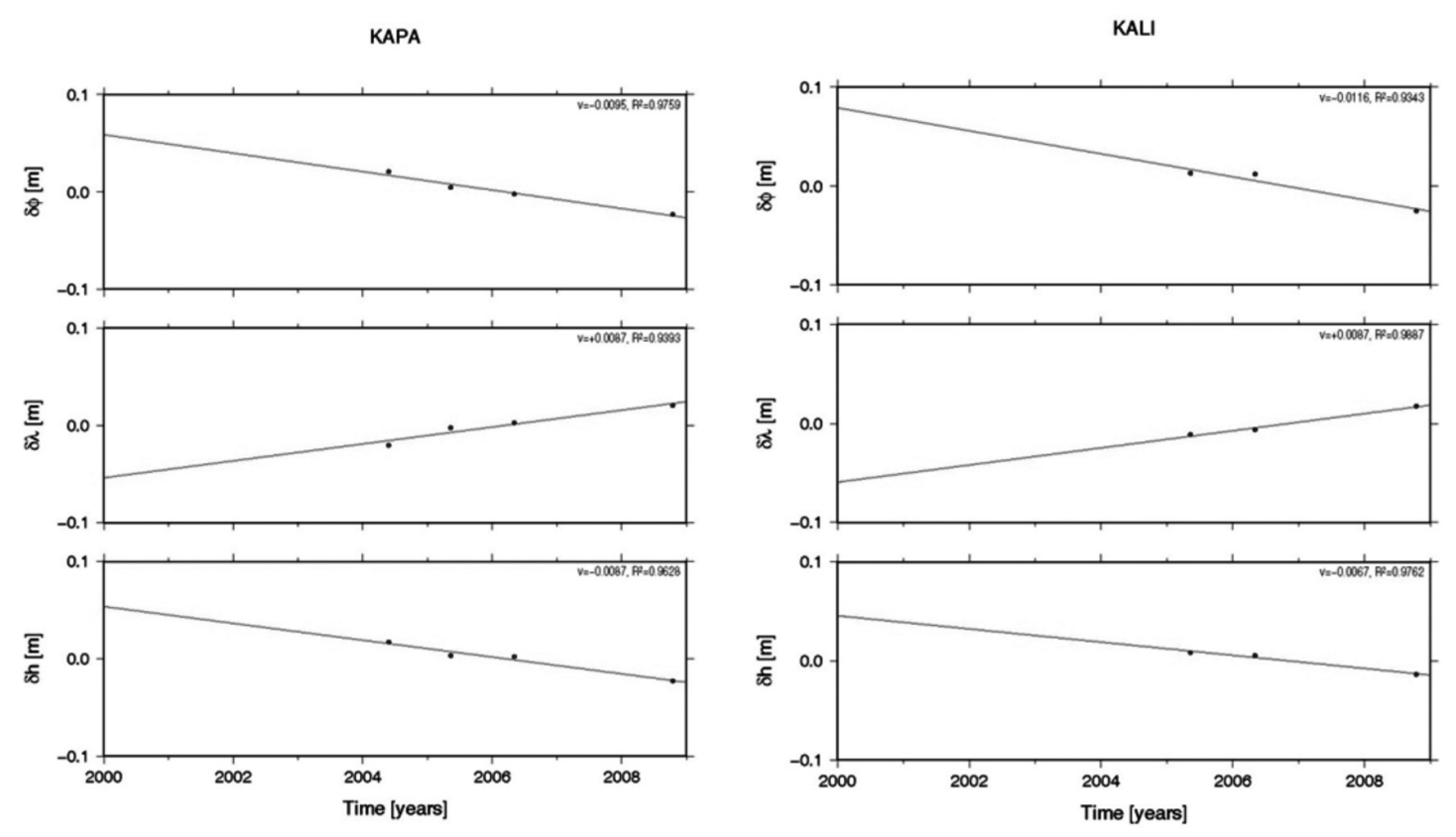

ERIT

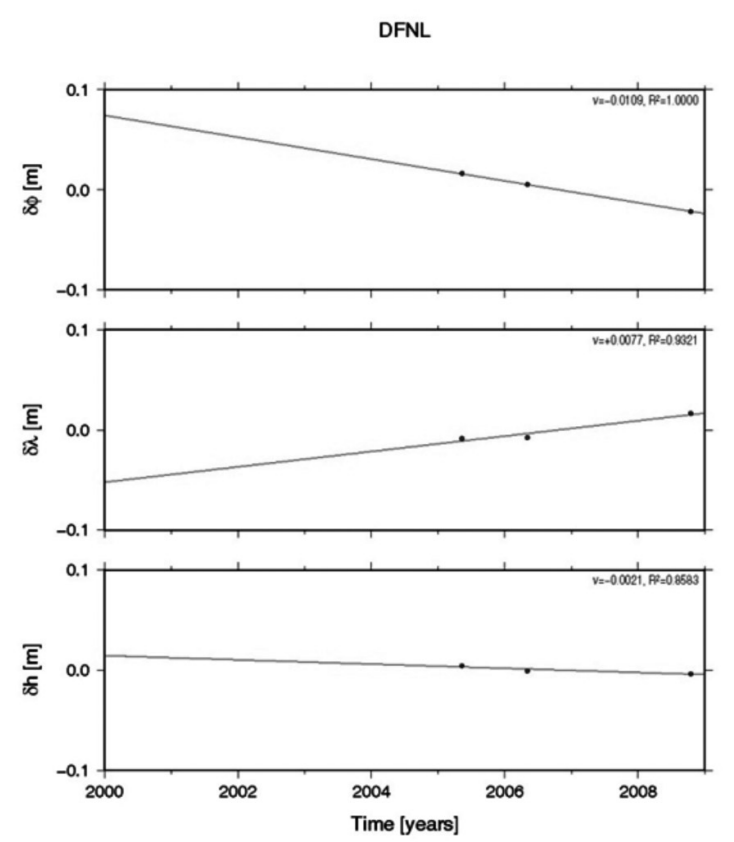

Figure 4. Graph with position time series (N, E, UP from top to bottom) from stations with 4 epochs of observations (KAPA and ERIT; a and c) and 3 epochs of observations (KALI and DFNL; b and d), respectively. Location of stations is shown in Figure $3 a$.

\subsection{Data analysis}

All data processing was carried out with the Bernese v5.0 software package [Dach et al. 2007], using IGS precise products for orbits, Earth rotation, relative receiver antenna Phase Center Variation (PCV) along with the respective satellite phase pattern file and CODE-produced Code Differential Bias (DCB) corrections. Local ionospheric models for baselines longer than $400 \mathrm{~km}$ were calculated, as well as local tropospheric models for the whole of the network. A single zenith path delay parameter was estimated every 2 hours per site for the tropospheric models. Automated cycle slip fixing was applied. The Quasi Ionosphere Free Strategy was used for the ambiguity resolution. A percentage (70\%) of ambiguities resolved was accepted. Next, all the baseline daily normal equations were stacked, to produce final coordinate estimates. For each epoch, the IGS station coordinates were kept fixed in order the final velocity field to be aligned to the ITRF2005 reference frame. The calculation consists of direct independent baselines formed by the local permanent network (2 station used for each epoch) which were radially connected with the sites of the local network.

\subsection{Results from GPS processing}

Times series were produced for each point in order to calculate the velocity in a three dimensional topocentric system (north, east, up; Figure 4). There were no sta- 


\begin{tabular}{cccccccccc} 
CODE & $\varphi^{\circ}$ & $\lambda^{\circ}$ & $\begin{array}{c}\mathbf{V n} \\
(\mathbf{m} / \mathbf{y})\end{array}$ & $\begin{array}{c}\sigma_{\mathrm{Vn}} \\
(\mathbf{m} / \mathbf{y})\end{array}$ & $\mathbf{R}^{2}$ & $\begin{array}{c}\mathbf{V e} \\
(\mathbf{m} / \mathbf{y})\end{array}$ & $\begin{array}{c}\sigma_{\mathrm{Ve}} \\
(\mathbf{m} / \mathbf{y})\end{array}$ & $\mathbf{R}^{2}$ & $\mathbf{V n o r m}$ \\
\hline ACLA & 38.2390 & 23.1671 & -0.020 & 0.001 & 0.969 & -0.014 & 0.001 & 0.962 & 0.024 \\
AGTR & 38.2081 & 23.2372 & -0.022 & 0.001 & 0.981 & -0.015 & 0.001 & 0.969 & 0.027 \\
ALYK & 38.2263 & 23.0453 & -0.018 & 0.001 & 0.988 & -0.015 & 0.000 & 0.999 & 0.023 \\
ASOP & 38.2913 & 23.4851 & -0.021 & 0.000 & 1 & -0.015 & 0.000 & 0.997 & 0.026 \\
DAFN & 38.2357 & 23.4187 & -0.024 & 0.001 & 0.991 & -0.014 & 0.000 & 0.999 & 0.028 \\
DFNL & 38.2587 & 23.4713 & -0.022 & 0.000 & 1 & -0.016 & 0.002 & 0.932 & 0.027 \\
ERIT & 38.2133 & 23.3393 & -0.022 & 0.000 & 0.999 & -0.014 & 0.001 & 0.985 & 0.026 \\
KALI & 38.3219 & 23.4206 & -0.023 & 0.003 & 0.934 & -0.015 & 0.001 & 0.986 & 0.027 \\
KAPA & 38.2313 & 23.2219 & -0.021 & 0.001 & 0.975 & -0.015 & 0.002 & 0.939 & 0.026 \\
TAPS & 38.1966 & 23.1459 & -0.021 & 0.001 & 0.984 & -0.014 & 0.001 & 0.969 & 0.025 \\
VILI & 38.1688 & 23.3031 & -0.022 & 0.001 & 0.985 & -0.013 & 0.001 & 0.982 & 0.026 \\
\hline
\end{tabular}

Table 1. Horizontal station velocities with respect to a stable Europe. $V_{N}$ indicates north component of velocity $(\mathrm{m} / \mathrm{yr})$ and $\mathrm{V}_{\mathrm{E}}$ indicates the east component. $\sigma$ indicates standard deviation of velocity $(\mathrm{m} / \mathrm{yr})$.

tistical tests applied to filter the times series due to the limitation of the amount of data. Despite that the density of the measurements is 3 epochs for 5 points and 4 for the rest six within four years the fit of the time series is quite good as it appears by examining the $\mathrm{R}^{2}$ indicator (less reliable results are obtained in the height component as expected). Stations observed in 3 epochs appear to move faster, which can either a "true" geologic signal or a result of epoch measurements and time span (first to third campaign). Future campaigns will confirm or modify this result. The final velocities of the 11 points with respect to a fixed Europe (using Yannick [2000]) are presented in Table 1 and in Figure 5. GPS velocities

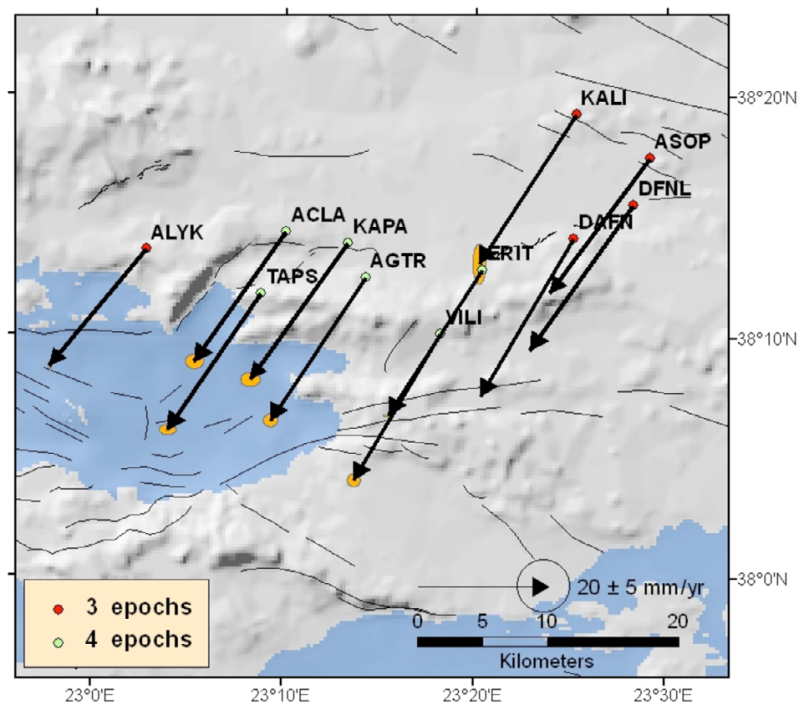

Figure 5. KAPNET station vectors for horizontal velocity from analysis described in the main text. Velocity reference frame is fixed to the stable interior of the Eurasia plate (Figure 3b). Error ellipses represent $95 \%$ confidence regions. Grey lines are active faults [Ganas et al. 2013b]. were calculated with an accuracy of a few $\mathrm{mm} / \mathrm{yr}$.

Furthermore, in order to explore the internal kinematics of the fault systems the velocity of specific GPS sites were subtracted in order to visualize the relative motion of points within the Asopos rift valley. In Figure 6 velocities with respect to point ACLA, VILI and ASOP accordingly are presented.

\subsection{Calculation of strain tensor parameters}

Strain tensors were calculated considering that Earth is deforming in 2 dimensions and that the Earth's crust is a thin deformable calotte on a spherical Earth. Space (faults) and time (earthquakes) discontinuities are not included in the calculation. For areas less than $5^{\circ} \times 5^{\circ}$ the mapping distortions do not exceed $10^{-3}$ in scale and therefore can be ignored without any practical loss of rigour. Least squares method was applied for the tensor of the whole region. The strain rate tensor of the whole region was calculated and is presented in Figure 7 and the corresponding deformation parameters in Table 2. The deformation of the region appears graphically by the convention used by the geophysics community: we plot the strain rates directly where a line shows the orientation of each principal axes (with a convention to tell us whether it is extensional or contractional; red for the former and blue for the latter) and a scale (Figure 7).

It is observed that the whole study area is undergoing extension with an azimuth of $\mathrm{N} 32^{\circ} \mathrm{W}$ while maximum strain rate reaches $187 \mathrm{~ns} / \mathrm{yr}$. Roberts and Ganas [2000] report that the regional extension direction is $\mathrm{N} 353^{\circ} \mathrm{E}$ (Corinth rift) vs. $\mathrm{N} 14^{\circ} \mathrm{E}$ (Evia rift). This systematic change is in agreement with the geodetic data from this study (Figure 7). In this region (to the east of the Gulf of Corinth), we are also interested in 

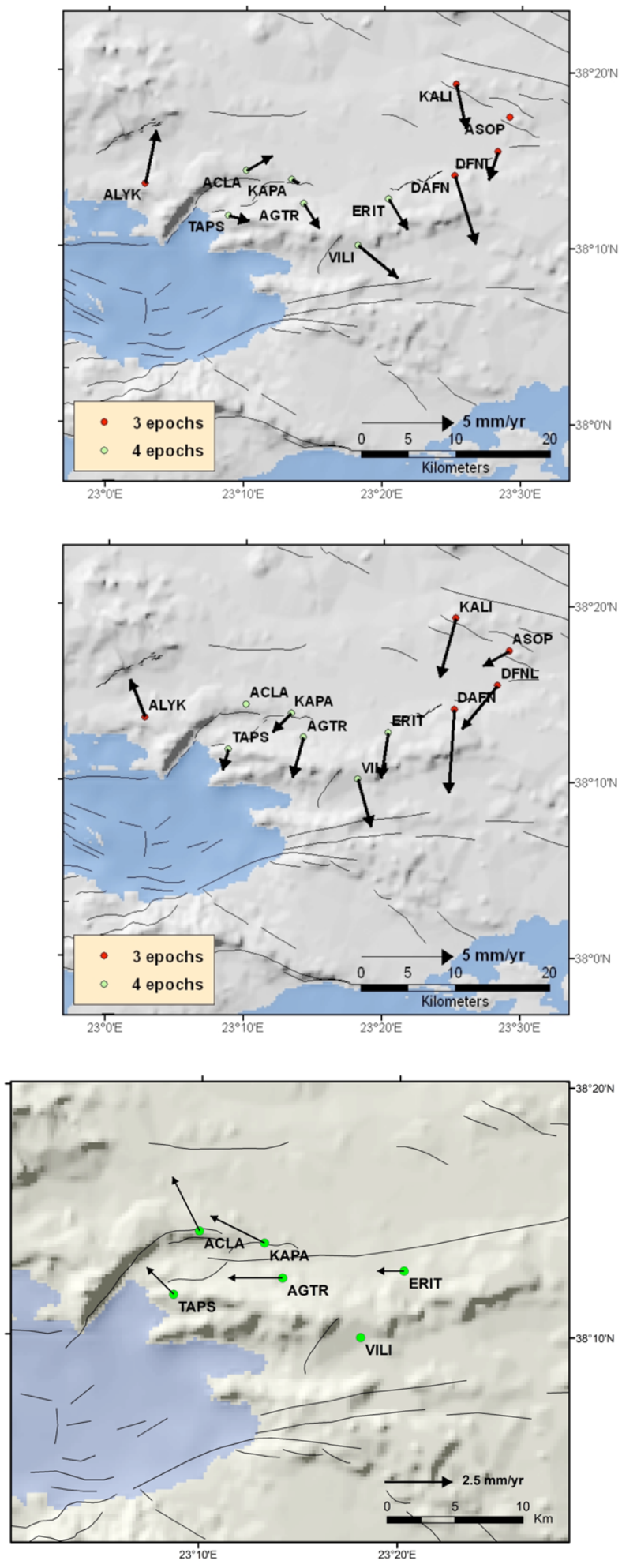

Figure 6 (top to bottom). Horizontal velocity vectors of KAPNET stations with respect to fixed ASOP (top) fixed ACLA (middle) and fixed VILI (bottom). Grey lines are active faults [Ganas et al. 2013b].

identifying the change in azimuth of the extensional and/or shortening strain rate axis in the east-west direction as this reflects the change in azimuth of major tectonic and possibly seismogenic structures. We form triangles between the sites that are relatively equilateral with most apex angles less than $\sim 30$ degrees. The strain rate tensors as well as the GPS sites participated in the

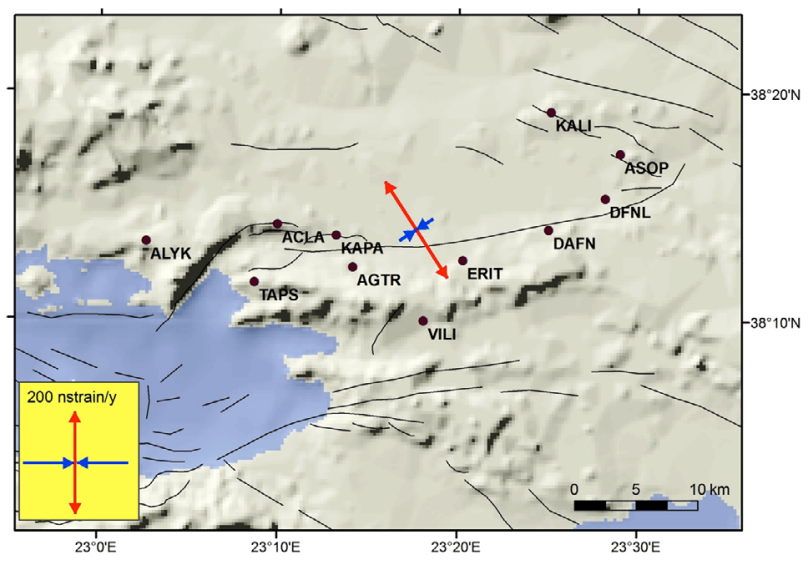

Figure 7. Strain rate field inferred from GPS velocities of the whole Kaparelli-Asopos region. Black solid circles indicate station locations. Red arrows indicate extension, blue arrows compression. 1 $\mathrm{ns} / \mathrm{yr}$ corresponds to an annual motion of $1 \mathrm{~mm}$ over a distance of $1000 \mathrm{~km}$. Grey lines are active faults [Ganas et al. 2013b].

\begin{tabular}{ccccc} 
Parameter & $\begin{array}{c}\text { Kmax } \\
(\mathbf{p p m})\end{array}$ & $\begin{array}{c}\text { Kmin } \\
(\mathbf{p p m})\end{array}$ & $\begin{array}{c}\mathrm{Az} \\
(\mathbf{d e g})\end{array}$ & $\begin{array}{c}\text { Shear } \gamma \\
(\mathbf{p p m})\end{array}$ \\
\hline Value & 0.187 & -0.066 & -32.744 & +0.253 \\
Error 1- $\sigma$ & 0.055 & 0.033 & 8.759 & 0.064 \\
\hline
\end{tabular}

Table 2. Deformation Parameters of the whole region (11 stations). The principal axes of the tensor are shown in Figure 8. The strain in this region consists of a small amount of compression in the direction approximately $\mathrm{N} 58^{\circ} \mathrm{E}$, and about three times more extension at $\mathrm{N} 32^{\circ} \mathrm{W}$ ( \pm 8 degrees).

calculation of the deformation accordingly are presented in Figure 8. All the deformation parameters are included in Table 3.

Our strain rate tensor results may be compared to recent results from continuous network data, such as by Chousianitis et al. [2013]. The latter results are based on the rigorous analysis of continuous GPS data with station spacing exceeding $50 \mathrm{~km}$, in other words the focus of that paper is regional not local as this study. In our study area, the paper by Chousianitis et al. [2013] considers two data points (see their Figure 3; cGPS stations THIV and 014A), both to the northeast of our study area. Despite the difference a) in station spacing and b) data processing, it is interesting to point out that the velocities of stations THIV (see Table 1 of Chousianitis et al. [2013]) and our campaign stations (see Table 1) are comparable w.r.t stable Europe: THIV Ve $=-16.2$ $\mathrm{mm} / \mathrm{yr}$ and $\mathrm{Vn}=-22.2 \mathrm{~mm} / \mathrm{yr}$ while our point $\mathrm{DFNL}$ shows $\mathrm{Ve}=-16.0 \mathrm{~mm} / \mathrm{yr}$ and $\mathrm{Vn}=-22.0 \mathrm{~mm} / \mathrm{yr}$ (point AGTR has Ve $=-15.0 \mathrm{~mm} / \mathrm{yr}$ and $\mathrm{Vn}=-22.0$ $\mathrm{mm} / \mathrm{yr}$; Figure 5). In addition, Figure $6 \mathrm{~A}$ of the Chousianitis et al. [2013] paper shows the Kaparelli study area as included in one triangle of their cGPS stations (namely THIV-KORI-015A) with triangle sides exceeding $50 \mathrm{~km}$ length. In this triangle, it is observed that the 
principal strain axis azimuth is clockwise from north (Figure 7 shows the opposite) and the size of the vector roughly exceeds $100 \mathrm{~ns} / \mathrm{yr}$ (Table 2 shows a value of 187 $\mathrm{ns} / \mathrm{yr}$ ). We explain this apparent difference as follows: the azimuth of the strain rate vector in the Chousianitis et al. [2013] paper is influenced by the choice of the triangle formed by cGPS stations. This result highlights the need for local GPS networks, able to map the local patterns of the strain rate tensor. Indeed, the azimuth of the strain rate vector in the northern triangle (stations THIV-015AATAL; Chousianitis et al. [2013]) is directed to the North while the further to the north triangle (stations 015AATAL-072A; Chousianitis et al. [2013]) shows an azimuth to the NNW. Second, the measured strain magnitude is a function of station distance, so it is reasonable to obtain a "smoother" magnitude of strain rate as station distance increases from $5 \mathrm{~km}$ (N-S; see Figure 5) to $50 \mathrm{~km}$ as in the paper by Chousianitis et al. [2013].

\section{Discussion}

GPS observations in Greece documented largescale continental extension across the Gulf of Corinth ( $\sim 1 \mathrm{~cm} / \mathrm{yr}$; Billiris et al. [1991] and progressive increase in plate motion velocities southward towards the forearc [Le Pichon et al. 1995, Kahle et al. 2000, McClusky et al. 2000, Ganas et al. 2013a]. Moreover, several groups conducted research on the kinematics of the upper crust in Greece suggesting models for several microplates or continental blocks [e.g. Avallone et al. 2004, Nyst and Thatcher 2004, Reilinger et al. 2006, Floyd et al. 2010, Chousianitis et al. 2013]. In central Greece, a first indication of a crustal block boundary was suggested by Nyst and Thatcher [2004] and Reilinger et al. [2006] using GPS data.

Our local data (Figure 7) collected in four (4) campaigns suggest that: a) significant strain accumulates

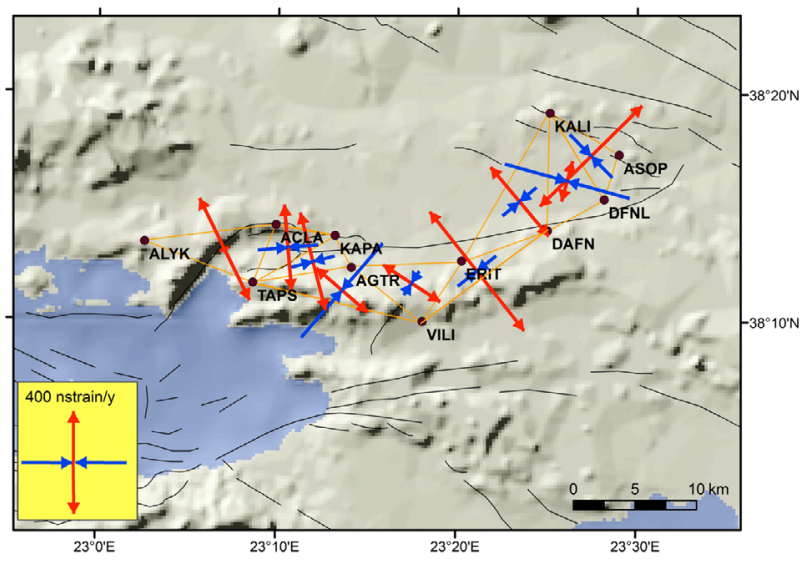

Figure 8. Strain tensors calculated inside station triangles for the eastern and western part of the area. Red arrows indicate extension, blue arrows compression. Grey lines are active faults [Ganas et al. 2013b].

across Kaparelli and Erithres faults, and b) the overall strain axis azimuth is oriented NW-SE. Moreover, the difference in strain axes orientation does not relate to a significant change in the GPS velocity field as we move from west (points TAPS, ACLA etc) to east (DAFN, ASOP etc). This is also evident from the comparison of the velocity fields in Figure 6 where remote stations ACLA was kept fixed and the resultant velocities of remaining stations were of sub-parallel directions (with exception of point ALYK). However, when station ASOP is kept fixed the western stations show a different velocity pattern. This needs further investigation with more campaign data collection to confirm or reject this pattern.

Moreover, looking the detailed strain patterns in Figure 8 (strain triangles) we find reasonable to suggest that an E-W crustal block boundary due to the Quaternary Corinth rift may be growing along and to the east of Kaparelli fault. By calculating station velocities with station VILI fixed (Figure 6) it is seen that points KAPA and ACLA move as a block to the northwest with

\begin{tabular}{ccccccc} 
code & $\varphi^{\circ}$ & $\lambda^{\circ}$ & Kmax & Kmin & $\begin{array}{c}\text { Az } \\
(\mathbf{d e g})\end{array}$ & $\begin{array}{c}\text { Shear } \boldsymbol{\gamma} \\
(\mathbf{p p m})\end{array}$ \\
\hline 1 & 38.221 & 23.119 & 0.369 & 0.034 & -26.063 & 0.335 \\
2 & 38.222 & 23.178 & 0.28 & -0.197 & -4.711 & 0.478 \\
3 & 38.212 & 23.202 & 0.329 & -0.145 & -14.435 & 0.475 \\
4 & 38.191 & 23.229 & 0.222 & -0.405 & 130.925 & 0.627 \\
5 & 38.197 & 23.293 & 0.221 & -0.093 & 122.973 & 0.315 \\
6 & 38.206 & 23.354 & 0.494 & -0.159 & -38.362 & 0.438 \\
7 & 38.257 & 23.393 & 0.294 & -0.144 & -40.051 & 0.556 \\
8 & 38.272 & 23.437 & 0.135 & -0.421 & 15.463 & 0.663 \\
9 & 38.291 & 23.459 & 0.466 & -0.198 & 45.469 & 0.247
\end{tabular}

Table 3. Strain parameters of the Kaparelli region using tectonic velocities from triangles of GPS sites. Geographic coordinates refer to triangle centroids. 
increased rates in comparison to stations AGTR and ERIT that also move as a block to the west. So a proposed boundary runs between stations ACLA and KAPA to the north and stations AGTR and ERIT to the south. Using the extension direction derived from the triangles VILI-ERIT-DAFN and ERIT-DAFN-KALI we suggest that the block boundary extends up to at least the area of station DAFN (Figure 8). The existence of the boundary is due to strain localisation along the subparallel, normal faults in this area of central Greece (see Figure 1). It is reasonable to link the kinematics and crustal extension across the Kaparelli fault to those of Alkyonides fault to the west [Morewood and Roberts 2002]. Similarly, it is suggested that kinematics and extension across the north-dipping Erithres fault are linked to those of the south-dipping Kaparelli fault to the west. To the east of point DAFN (Dafni) there is a change in extension direction due to local kinematics, i.e. the south-dipping faults accommodating strain maybe more than one [e.g. Tsodoulos et al. 2008, Sboras et al. 2010] and with different orientations, so the extension direction across the Asopos rift (further east) is different from that across the Erithres fault (Figure 1). This needs more geological data (fault slip vectors) to establish and more GPS campaigns to establish reliable strain patterns.

\section{Conclusions}

1. The velocity field vectors w.r.t. Eurasia (Figure 5) computed from the 2004, 2005, 2006 and 2008 measurements appear consistent with other kinematic studies in central Greece [e.g. McClusky et al. 2000, Veis et al. 2007, Floyd et al. 2010, Chousianitis et al. 2013].

2. Preliminary strain tensors were calculated for the whole region ( $40 \mathrm{~km} \mathrm{E-W} \times 12 \mathrm{~km} \mathrm{~N}-\mathrm{S}$ ) and across the Kaparelli and Erithrai normal faults. The strain consists of a small amount of compression in the direction approximately $\mathrm{N} 58^{\circ} \mathrm{E}$, and about three times more extension at $\mathrm{N} 32^{\circ} \mathrm{W}$. Extension in this direction is estimated to $187 \mathrm{~ns} / \mathrm{yr}$.

3. It is observed that extension direction changes from west to east. Across the Kaparelli and Erithres fault extension is NW-SE, while across the fault segment to the east is NNE-SSW. This result has to be validated with more GPS campaigns in the future. This change signifies the need for using local GPS networks to map local strain patterns in actively extending regions such as the Asopos - north Parnitha region of central Greece.

4. The above result is in agreement with geological data [Roberts and Ganas 2000, Ganas et al. 2007b, Tsodoulos et al. 2008] as fault slip data in the greater Kaparelli region document local changes in the extension direction.
Acknowledgements. This research was primarily funded by COST Action 625. We thank our colleagues Xanthos Papanikolaou, Jarek Bosy, Witold Rohm, Demitris Anastasiou, George Drakatos, Stefan Cacon and Bernard Kontny for discussions on data processing and help with data collection. We acknowledge useful comments by S. Pavlides, I. Koukouvelas, E. Tondi and V. Spina. We thank our NOA colleagues Th. Vourakis, G. Mihalettos, I. Papastamatiou, M. Papanikolaou, V. Korakas and A. Pirentis for help with network setup. Many thanks are due to E. Skassis for this help with GPS instrumentation.

\section{References}

Ambraseys, N.N., and J.A. Jackson (1990). Seismicity and associated strain of central Greece between 1890 and 1988, Geophys. J. Int., 101 (3), 663-708.

Armijo, R., B. Meyer, G.C.P. King, A. Rigo and D. Papanastasiou (1996). Quaternary evolution of the Corinth Rift and its implications for the Late Cenozoic evolution of the Aegean, Geophys. J. Int., 126, 11-53.

Atzori, S., M. Manunta, G. Fornaro, A. Ganas and S. Salvi (2008). Postseismic displacement of the 1999 Athens earthquake retrieved by the Differential Interferometry by Synthetic Aperture Radar time series, J. Geophys. Res., 113, B09309; doi:10.1029/2007 JB005504.

Avallone, A., P. Briole, A.M. Agatza-Balodimou, H. Billiris, O. Charade, C. Mitsakaki, A. Nercessian and G. Veis (2004). Analysis of eleven years of deformation measured by GPS in the Corinth Rift Laboratory area, Comptes Rendus - Geoscience, 336 (4-5), 301311; doi:10.1016/j.crte.2003.12.007.

Bell, R.E., L.C. McNeill, J.M. Bull, T.J. Henstock, R.E.L. Collier and M.R. Leeder (2009). Fault architecture, basin structure and evolution of the Gulf of Corinth rift, central Greece, Basin Research, 21 (6), 824-855.

Benedetti, L., R. Finkel, G. King, R. Armijo, D. Papanastassiou, F.J. Ryerson, F. Flerit, D. Farber and G. Stavrakakis (2003). Motion on the Kaparelli fault (Greece) prior to the 1981 earthquake sequence determined from ${ }^{36} \mathrm{Cl}$ cosmogenic dating, Terra Nova, 15, 118-124

Billiris, H., D. Paradissis, G. Veis, P. England, W. Featherstone, B. Parsons, P. Cross, P. Rands, M. Rayson, P. Sellers, V. Ashkenazi, M. Davison, J. Jackson and N. Ambraseys (1991). Geodetic determination of tectonic deformation in central Greece from 1900 to 1988, Nature, 350, 124-129.

Cacon, S., B. Kontny, J. Bosy, G. Cello, L. Piccardi, E. Tondi, G. Drakatos and A. Ganas (2005). Local geodynamic researches in Sudetes and the Mediterranean Region, Reports on Geodesy, 2 (73), 231-244.

Chousianitis, K., A. Ganas and M. Gianniou (2013). Kinematic interpretation of present-day crustal deformation in central Greece from continuous GPS 
measurements, J. Geodyn., 71, 1-13.

Clarke, P.J., R.R. Davies, P.C. England, B. Parsons, H. Billiris, D. Paradissis, G. Veis, P.A. Cross, P.H. Denys, V. Ashkenazi, R. Bingley, H.G. Kahle, M.V. Muller and P. Briole (1998). Crustal strain in central Greece from repeated GPS measurements in the interval 1989-1997, Geophys. J. Int., 135, 195-214.

Collier, R.E.L., D. Pantosti, G. D’Addezio, P.M. De Martini, E. Masana and D. Sakellariou (1998). Paleoseismicity of the 1981 Corinth earthquake fault: Seismic contribution to extensional strain in central Greece and implications for seismic hazard, J. Geophys. Res. B: Solid Earth, 103 (B12), 30001-30019.

Dach, R., U. Hugentobler, P. Fridez and M. Meindl (2007). Bernese GPS software version 5.0, Astronomical Institute, University of Bern, 640.

Drakatos, G., L. Petro, A. Ganas, N. Melis, B. Kostak, B. Kontny, S. Cacon and M. Stercz (2005). Monitoring of strain accumulation along active faults in the eastern Gulf of Corinth: Instrumentation and network setup, Acta Geodyn. Geomater., 2, 1 (137), 13-23.

Floyd, M.A., H. Billiris, D. Paradissis, G. Veis, A. Avallone, P. Briole, S. McClusky, J.M. Nocquet, K. Palamartchouk, B. Parsons and P.C. England (2010). A new velocity field for Greece: Implications for the kinematics and dynamics of the Aegean, J. Geophys. Res., 115 (B10403); doi:10.1029/2009JB007040.

Ganas, A., S.B. Pavlides, S. Valkaniotis, S. Sboras, S. Papaioannou, G.A. Alexandris, A. Plessa and G.A. Papadopoulos (2004). Active Fault Geometry and Kinematics in Parnitha Mountain, Attica, Greece, J. Struct. Geol., 26, 2103-2118.

Ganas, A., S. Pavlides and V. Karastathis (2005). DEMbased morphometry of range-front escarpments in Attica, central Greece, and its relation to fault slip rates, Geomorphology, 65, 301-319.

Ganas, A., J. Bosy, L. Petro, G. Drakatos, B. Kontny, M. Stercz, N.S. Melis, S. Cacon and A. Kiratzi (2007a). Monitoring active structures in eastern Corinth Gulf (Greece): The Kaparelli fault, Acta Geodyn. Geomater., 4 (1), 67-75.

Ganas, A., V. Spina, N. Alexandropoulou, A. Oikonomou and G. Drakatos (2007b). The Corini active fault in south-western Viotia region, central Greece: segmentation, stress analysis and extensional strain patterns, Bulletin of the Geological Society of Greece, 40, 297-308.

Ganas, A., A. Marinou, D. Anastasiou, D. Paradissis, K. Papazissi, P. Tzavaras and G. Drakatos (2013a). GPSderived estimates of crustal deformation in the central and north Ionian Sea, Greece: 3-yr results from NOANET continuous network data, J. Geodyn., 67, 62-71; http: / / dx.doi.org/10.1016/j.jog.2012.05.010.
Ganas, A., A.I. Oikonomou and C. Tsimi (2013b). NOAFAULTS: a digital database for active faults in Greece, Bulletin of the Geological Society of Greece, 47 (Proceedings of the 13th International Congress, Chania, September 2013), 518-530.

Goldsworthy, M., and J. Jackson (2000). Active normal fault evolution in Greece revealed by geomorphology and drainage patterns, J. Geol. Soc. London, 157, 967-981.

Goldsworthy, M., and J. Jackson (2001). Migration of activity within normal fault systems: examples from the Quaternary of mainland Greece, J. Struct. Geol., 23, 489-506.

Hubert, A., G. King, R. Armijo, B. Meyer and D. Papanastasiou (1996). Fault Re-activation, Stress Interaction and Rupture Propagation of the 1981 Corinth Earthquake Sequence, Earth Planet. Sci. Lett., 142, 573-585.

IGME, Institute of Geology and Mineral Exploration (1984). Geological map of Greece, Kaparellion Sheet, scale 1:50,000.

Jackson, J.A., et al. (1982). Seismicity, normal faulting and the geomorphological development of the Gulf of Corinth (Greece): the Corinth earthquakes of February and March 1981, Earth Planet. Sci. Lett. 57, 377-397.

Kahle, H.-G., M. Cocard, Y. Peter, A. Geiger, R. Reilinger, A. Barka and G. Veis (2000). GPS-derived strain rate field within the boundary zones of the Eurasian, African, and Arabian Plates, J. Geophys. Res., 105 (B10), 23353-23370.

Kokkalas, S., S. Pavlides, I. Koukouvelas, A. Ganas and L. Stamatopoulos (2007). Paleoseismicity of the Kaparelli fault (eastern Corinth Gulf): Evidence for earthquake recurrence and fault behaviour, Bollettino della Società Geologica Italiana, 126 (2), 387-395.

Le Pichon, X., N. Chamot-Rooke, S. Lallemant, R. Noomen and G. Veis (1995). Geodetic determination of the kinematics of central Greece with respect to Europe: implications for eastern Mediterranean tectonics, J. Geophys. Res., 100 (B7), 12675-12690.

Mahmoud, Y., F. Masson, M. Meghraoui, Z. Cakir, A. Alchalbi, H. Yavasoglu, O. Yönlü, M. Daoud, S. Ergintav and S. Inan (2013). Kinematic study at the junction of the East Anatolian fault and the Dead Sea fault from GPS measurements, J. Geodyn., 67, 30-39; ISSN 0264-3707, http:/ / dx.doi.org/10.1016/ j.jog.2012.05.006.

McClusky, S., et al. (2000). Global Positioning System constraints on plate kinematics and dynamics in the eastern Mediterranean and Caucasus, J. Geophys. Res., 105 (B3), 5695-5719; doi:10.1029/1999JB900351.

Morewood, N.C., and G.P. Roberts (2002). Surface ob- 
servations of active normal fault propagation: implications for growth, J. Geol. Soc. London, 159, 263-272.

Nyst, M., and W. Thatcher (2004). New constraints on the active tectonic deformation of the Aegean, J. Geophys. Res., 109 (B11406), doi:10.1029/ 2003JB002830.

Papadopoulos, G.A., A. Ganas and S. Pavlides (2002). The problem of seismic potential assessment: Case study of the unexpected earthquake of 7 September 1999 in Athens, Greece, Earth Planets Space, 54, 9-18.

Papazachos, B., and C. Papazachou (1997). The Earthquakes of Greece, Editions Ziti, Thessaloniki, 304 pp.

Pavlides, S., I. Koukouvelas, A. Ganas, S. Kokkalas, I. Tsodoulos, L. Stamatopoulos, C. Gountromichou and S. Valkaniotis (2003). Preliminary palaeoseismological results from the Kaparelli faul (Central Greece), Contribution EAE03-A-07069 for the EGSAGU-EUG Joint Assembly (Nice, France, April 2003).

Poulimenos, G., and T. Doutsos (1996). Barriers on seismogenic faults in central Greece, J. Geodyn., 22 (1-2), 19-135; doi:10.1016/0264-3707(96)00006-3.

Reilinger, R., et al. (2006). GPS constraints on continental deformation in the Africa-Arabia-Eurasia continental collision zone and implications for the dynamics of plate interactions, J. Geophys. Res., 111 (B05411); doi:10.1029/2005JB004051.

Roberts, G.P., and A. Ganas (2000). Fault-slip directions in central and southern Greece measured from striated and corrugated fault planes: comparison with focal mechanism and geodetic data, J. Geophys. Res., 105, 23443-23462.

Sboras, S., A. Ganas and S. Pavlides (2010). Morphotectonic analysis of the neotectonic and active faults of Beotia (central Greece), using GIS techniques, Bulletin of the Geological Society of Greece, 43 (Proceedings of 12th International Conference, Patras, May 2010), 3, 1607-1618.

Stiros, S.C., P. Psimoulis and S. Pitharouli (2007). Geodetic constraints to the kinematics of the Kapareli fault, reactivated during the 1981, Gulf of Corinth earthquakes, Tectonophysics, 440 (1-4), 105-119; doi:10.1016/j.tecto.2007.02.006.

Tsimi, Ch., and A. Ganas (2015). Using the ASTER global DEM to derive empirical relationships among triangular facet slope, facet height and slip rates along active normal faults, Geomorphology, 234, 171-181.

Tsodoulos, I.M, I.K. Koukouvelas and S. Pavlides (2008). Tectonic geomorphology of the easternmost extension of the Gulf of Corinth (Beotia, Central Greece), Tectonophysics, 453 (1-4), 211-232.

Veis, G., H. Billiris, C. Papazissi and A. Marinou (2007). Tectonic motions in the Aegean and inside the triangle Alkyonides-Parnitha-Atalanti, Technika Chronika, 3 (in Greek); http:/ / portal.tee.gr/portal/page/por
tal/PUBLICATIONS/SCIENTIFIC_PUBLICATIO NS/SEIRA_I/ETOS_2007/tefhosC/04_1.pdf.

Walker, R.T, S. Claisse, M. Telfer, E. Nissen, P. England, C. Bryant and R. Bailey (2010). Preliminary estimate of Holocene slip-rate on active normal faults bounding the southern coast of the Gulf of Evia, central Greece, Geosphere, 6, 583-593.

Whittaker, A.C., and A.S. Walker (2015). Geomorphic constraints on fault throw rates and linkage times: Examples from the Northern Gulf of Evia, Greece, J. Geophys. Res.: Earth Surface, 120; ISSN 2169-9003. Yannick, F.P. (2000). Present-day crustal dynamics in the Adriatic and Aegean plate boundary zone inferred from continuous GPS-measurements, $\mathrm{PhD}$ thesis, no. 13700, ETH, Zurich.

Corresponding author: Aggeliki Marinou, Higher Geodesy Laboratory, N.T.U.A., Faculty of Rural and Surveying Engineering, Zographos, Greece; email: amarinou@survey.ntua.gr.

C 2015 by the Istituto Nazionale di Geofisica e Vulcanologia. All rights reserved. 